\title{
Rain-generated overland flow as a factor in the development of some stratified slope deposits: A case study from the Pays du Buëch (Préalpes, France) \\ Le rôle du ruissellement d'origine pluviale dans la genèse d'un certain type d'éboulis stratifié : une étude de cas réalisée au Pays du Buëch (Préalpes du Sud, France) \\ Abspülung durch Regenwasser als Faktor bei der Entwicklung gewisser Typen geschichteter Hangschuttablagerungen. Ein Beispiel aus dem Pays du Buëch (Préalpes, Frankreich)
}

Henk van Steijn et Bernard Hétu

Volume 51, numéro 1, 1997

URI : https://id.erudit.org/iderudit/004884ar

DOI : https://doi.org/10.7202/004884ar

\section{Aller au sommaire du numéro}

\section{Éditeur(s)}

Les Presses de l'Université de Montréal

\section{ISSN}

0705-7199 (imprimé)

1492-143X (numérique)

\section{Découvrir la revue}

\section{Citer cet article}

van Steijn, H. \& Hétu, B. (1997). Rain-generated overland flow as a factor in the development of some stratified slope deposits: A case study from the Pays du Buëch (Préalpes, France). Géographie physique et Quaternaire, 51(1), 3-15. https://doi.org/10.7202/004884ar

\section{Résumé de l'article}

La dynamique de surface d'un talus d'éboulis stratifié partiellement actif a été étudiée en détail dans le but d'en comprendre la stratigraphie, exposée dans une grande gravière à la base du talus. Elaboré à la charnière Pléistocène-Holocène, cet éboulis est situé en France, dans la vallée du Buëch près de Veynes, Préalpes du Sud. Sur le versant actif, partiellement couvert d'arbustes, les processus dominants sont les coulées de pierres sèches, l'érosion pluviale et les 'coulées d'agrégats' associées aux fortes pluies. Ces dernières correspondent à de petites laves de ruissellement comprenant une forte proportion d'agrégats limoneux de 0,5 à $3 \mathrm{~mm}$ de diamètre. Ces trois processus interviennent en séquence, définissant une chaîne de processus qui produit des dépôts stratifiés. Les formes et les sédiments associés à ces processus sont décrits en détail. Les résultats sont ensuite utilisés comme cadre de référence lors de l'interprétation des dépôts anciens exposés dans la gravière. Entre les dépôts actuels et les dépôts anciens, on note à la fois des similitudes et des différences. Les premières confirment la validité du modèle proposé ; les secondes soulèvent différents problèmes qui sont discutés (altération des signatures sédimentaires avant et après l'enfouissement des dépôts ; intervention d'autres processus). Ce type d'éboulis stratifié, élaboré par des processus azonaux, n'a en soi aucune signification climatique précise. 


\section{RAIN-GENERATED OVERLAND FLOW AS A FACTOR IN THE DEVELOPMENT OF SOME STRATIFIED SLOPE DEPOSITS: A CASE STUDY FROM THE PAYS DU BUËCH (PRÉALPES, FRANCE)}

Henk van STEIJN, The Netherlands Centre for Geo-ecological Research, Faculty of Geographical Sciences, Utrecht University, Heidelberglaan 2, P.O.Box 80.115, 3508 TC Utrecht, The Netherlands, H.vanSteyn@frw.ruu.nl.

Bernard HÉTU, Module de Géographie, Université du Québec à Rimouski, 300, allée des Ursulines, Rimouski, Québec, G5L $3 \mathrm{~A}$.

Manuscrit reçu le 7 mars 1996 ; manuscrit révisé accepté le 22 août 1996

ABSTRACT A large exposure of stratified slope deposits, and a partly vegetated active talus, both situated near Veynes (Préalpes du Sud, France) were studied. On the active slope, dry grain flows, erosion by rain-generated overland flow, and 'aggregate' flows caused by high-intensity rainstorms are most typical. The term 'aggregate' flow was chosen because of the abundant presence of silty aggregates (diameter $0.5-3 \mathrm{~mm}$ ) within these deposits which closely resemble small debris flows. These three processes operate in a fixed sequence thus producing a characteristic stratification pattern. Forms and sediments caused by the processes mentioned are described in detail. Subsequently, the results are applied in the interpretation of the sections of the relict deposits. The correlation and the interpretation problems with regard to processes involved between deposits on the active slope and within the relict sediment mass are discussed, together with the traces of other processes recognised within the latter. The results are placed in a wider context of stratified slope deposits and their palaeoclimatic significance.
RÉSUMÉ Le rôle du ruissellement d'origine pluviale dans la genèse d'un certain type d'éboulis stratifié: une étude de cas réalisée au Pays du Buëch (Préalpes du Sud, France). La dynamique de surface d'un talus d'éboulis stratifié partiellement actif a été étudiée en détail dans le but d'en comprendre la stratigraphie, exposée dans une grande gravière à la base du talus. Elaboré à la charnière Pléistocène-Holocène, cet éboulis est situé en France, dans la vallée du Buëch près de Veynes, Préalpes du Sud. Sur le versant actif, partiellement couvert d'arbustes, les processus dominants sont les coulées de pierres sèches, l'érosion pluviale et les 'coulées d'agrégats' associées aux fortes pluies. Ces dernières correspondent à de petites laves de ruissellement comprenant une forte proportion d'agrégats limoneux de 0,5 à $3 \mathrm{~mm}$ de diamètre. Ces trois processus interviennent en séquence, définissant une chaîne de processus qui produit des dépôts stratifiés. Les formes et les sédiments associés à ces processus sont décrits en détail. Les résultats sont ensuite utilisés comme cadre de référence lors de l'interprétation des dépôts anciens exposés dans la gravière. Entre les dépôts actuels et les dépôts anciens, on note à la fois des similitudes et des différences. Les premières confirment la validité du modèle proposé; les secondes soulèvent différents problèmes qui sont discutés (altération des signatures sédimentaires avant et après l'enfouissement des dépôts ; intervention d'autres processus). Ce type d'éboulis stratifié, élaboré par des processus azonaux, n'a en soi aucune signification climatique précise.
ZUSAMMENFASSUNG Abspülung durch Regenwasser als Faktor bei der Entwicklung gewisser Typen geschichteter Hangschuttablagerungen. Ein Beispiel aus dem Pays du Buëch (Préalpes, Frankreich). Ein Aufschluss in geschichteten Hangschuttablagerungen, situiert in der Umgebung von Veynes (Préalpes du Sud, Frankreich), sowie die teils bewachsene, aktive Schutthalde neben der Grube wurden untersucht. Auf der aktiven Schutthalde wurden (trockene) matrixlose Steinströme, durch Regen generierte Abspülung und mit (extremen) Starkregen verbundenen, Murgangähnliche 'Aggregat'-Ströme als die meist charakteristischen Prozesse festgestellt. Die Andeutung 'Aggregatströme' wurde gewählt aufgrund der Anwesenheit zahlloser kleinen Aggregate (Diameter 0.5-3 mm) aus Schluff oder Sand in den betroffenen Sedimenten. Die drei genannten Prozesse arbeiten in einer Catena-artigen Sequenz, welche zu der Entstehung geschichteter Ablagerungen führt. Geländeforme und Sedimente verursacht durch die betroffenen Prozesse wurden ausführlich dokumentiert, wonach die Ergebnisse verwendet wurden bei der Interpretation der Profile die in den Reliktablagerungen untersucht wurden. Korrelations- und Interpretationsprobleme bei dem Vergleich zwischen Ablagerungen der 'aktiven' Schutthalde und Reliktsedimente werden besprochen, vor allem hinsichtlich der Prozessrekonstruktion. Die Ergebnisse werden schliesslich diskutiert in im weiteren Kontext der palaeoklimatischen Bedeutung der geschichteten Hangschuttablagerungen. 


\section{INTRODUCTION}

Recent work on stratified slope deposits (Wasson, 1979; Van Steijn, 1988; Francou, 1989; 1990; Hétu, 1991; 1995; Hétu et al., 1994, 1995; Bertran et al., 1992, 1993) shows that the strong emphasis on periglacial conditions in the interpretation of these deposits in earlier publications (see Tricart and Cailleux, 1967; French, 1976; Washburn, 1979) should be weakened. Non-periglacial or azonal processes must be taken into account as well. A particular process in this context is overland flow caused by high-intensity rainfall. Apparently, on porous surfaces such as scree slopes, surface runoff can be generated if certain conditions exist.

The aim of the present article is twofold. First, to demonstrate the possible role of overland flow caused by highintensity rainfall in the building-up of certain types of stratified slope deposits found in the westernmost part of the French Alps. Second, as a consequence of the introductory statement, to stress the need of reconsidering the palaeoclimatic significance of stratified slope deposits.
Traces of present-day processes were analysed on a partly vegetated slope near a gravel pit in which relict deposits were studied. This slope is the present-day surface developed in the scree that is exposed in the gravel pit. It follows that the processes on the present-day slope act on the same material as found in the relict deposits. This facilitated the use of observations from the modern environment in the interpretation of the relict deposit, the final goal of the study.

\section{SITE DESCRIPTION}

The deposit studied is situated some kilometres west of Veynes along the Buëch river, a right-hand tributary of the Durance river in France (Fig. 1). The region belongs to the Préalpes du Sud in which intensively folded and faulted sedimentary rocks are present, most of them of Mesozoic age (Debelmas, 1974). Comparable slope deposits occur at several places in this region. Their age is not well known. Generally, they are considered to be of Würm age (without much better specification) if they are found at low relative altitudes
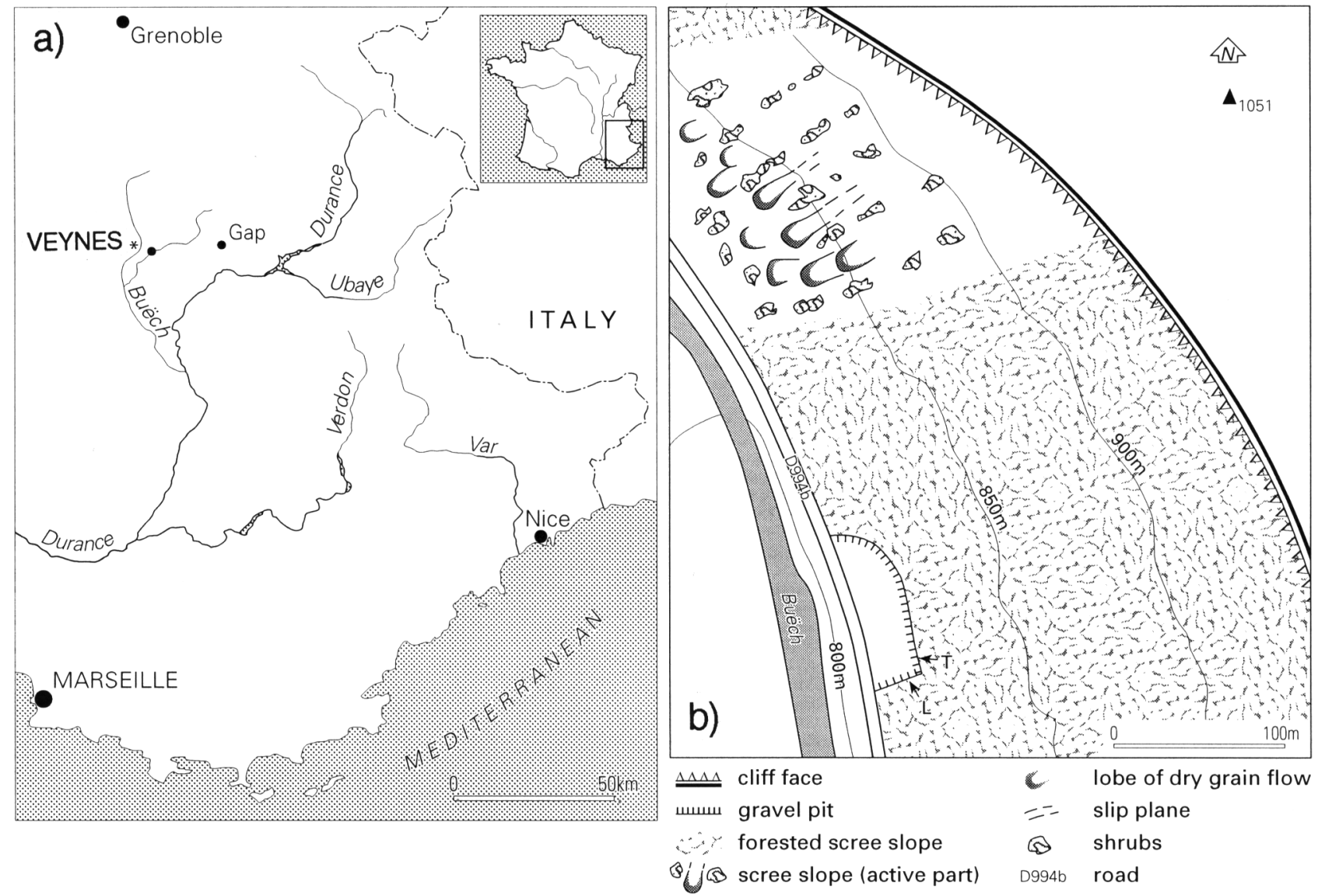

FIGURE 1. a) Location map. The position of the scree deposit studied is marked by an asterisk. b) Schematic map showing spatial arrangement of sites analysed. Transect on 'active' slope is situated at the southernmost slip-plane/grain-flow succesion shown. Approximate position of sections described indicated as $L$ (longitudinal section) and $T$ (transverse section). Local culmination point is also indicated (1051 $\mathrm{m}$ ).

a) Localisation de l'éboulis étudié, le site étant marqué par un astérisque. b) Croquis topographique de l'éboulis et des éléments étudiés. Le transect sur le versant 'actif' se trouve sous l'ensemble formé d'une suite de coulées sèches et de plans de glissement. L: position approximative de la coupe saggitale; T: coupe transversale. Le point coté 1051 indique le point culminant local. 
or when they can be correlated with river terraces dated as Würm (Jorda, 1988). However, in our case the position of the deposit does not exclude a possible (early) Holocene origin (Jorda, 1988; Gautier 1992).

The present-day climate of the region has Mediterranean characteristics modified by the influence of the mountain relief. The station of Laragne $(575 \mathrm{~m})$, about $20 \mathrm{~km}$ south of Veynes, has a mean annual air temperature of $11.0^{\circ} \mathrm{C}$. Mean temperatures for January and July are $1.0^{\circ} \mathrm{C}$ and $20.6^{\circ} \mathrm{C}$ respectively. Mean annual precipitation at Laragne is $838 \mathrm{~mm}$; July and August are the driest months. High-intensity rain storms occur in summer and autumn. During such storms, peaks of $>100-130 \mathrm{~mm} / \mathrm{h}$ for $2-5$ minutes are observed (Descroix, 1989; Blijenberg, 1993).

The gravel pit which is at $820 \mathrm{~m}$ a.s.l. is cut into a scree slope below a steep cliff (Fig. 1b). Local summits reach altitudes of about $1200-1400 \mathrm{~m}$. The top part of the talus is at about $940 \mathrm{~m}$ while its base nearly reaches the Buëch river $(790 \mathrm{~m})$. The aspect of the slope is WSW. Most of the scree slope is covered by an open forest of deciduous trees.

The cliff zone over the talus shows a succession of Jurassic sediments, comprising in downcliff direction: lithographic limestones in layers of 0.4-0.7 m, massif layers of calcareous conglomerate, and marly limestones in layers of variable thickness $(0.1-1 \mathrm{~m})$ between which thin lenses of marls occur. The total thickness of this succession is $50-60 \mathrm{~m}$. The lower part of the slope, where the scree accumulation is covering bedrock, consists of thinly layered limestones in which more marly intercalations are present than in the younger sediments higher upslope.

The sections from which parts are described are the walls of an abandoned gravel pit cut into the lower part of the scree slope. The main pit wall, about $50 \times 10 \mathrm{~m}$, provides a vertical section perpendicular to the local slope direction. The lower part of the original cut is invisible because of the accumulation of waste material. A small, triangular section having a base of about $10 \mathrm{~m}$ and a minimal height of about 2 $\mathrm{m}$, runs parallel to the local slope direction. Close to the excavation a part of the natural slope in the scree accumulation has been reactivated due to road construction (Fig. 1b). Here, the vegetation cover is less than $50 \%$. Only patches of shrubs and some small trees are found. A part of this 'active' slope was studied for traces of present-day processes. It consists of two main elements: an upper part (length 40-50 $\mathrm{m}$, slope angle $38-39^{\circ}$ ) in which traces of erosion prevail, and a lower part (length $40-50 \mathrm{~m}$, slope angle about $36^{\circ}$ ) immediately below the former where accumulation is general.

\section{METHODS}

Fieldwork, carried out in August 1993, consisted of a detailed survey of representative parts of the 'active' slope and of the stratified slope deposits exposed in the gravel pit in order to obtain a general image of processes involved in the development of the scree deposit. The emphasis was on morphological and detailed sedimentological observations at 'field scale'.

Work on the 'active' slope comprised:

- A transect study: description of the morphosedimentary phenomena at the present-day surface along a representative part of the slope that covers the two main constituents mentioned before; interpretation of sedimentary characteristics observed on the surface and in shallow sections with regard to depositional processes.

- Analysis of the role of vegetation patches and of microtopography in controlling the distribution of erosion and accumulation on the slope.

- Analysis of deposits left by overland flow.

Because only one week could be spent in the field during which no rain occurred, direct observation of rainfall effects was not possible. Evidence of erosion however was abundant (see below) and a few features of overland-flow initiation and sediment detachment caused by artificially generated runoff could be noticed.

The study of the sections in the pit was restricted mainly by the fact that many parts of them could not be reached. Therefore, two representative parts of $2 \times 3 \mathrm{~m}$ and $2 \times 2 \mathrm{~m}$ respectively were analysed in detail. One of these sections is a part of the main wall of the pit (transverse section). The other one is a part of the smaller triangular wall (longitudinal section).

The visible geometry of the different units was measured as accurately as possible, while their sedimentary properties are described in a more generalised way. The following observations were made: geometry of sedimentary units; form and character of boundaries between units; global grainsize characteristics, measured using a simple ruler for gravely material; and estimated manually and visually for the matrix (if present); presence and type of grading features; sorting (mainly established in a qualitative way); lateral transitions within beds and/or lenses.

Fabric measurements were made in three units (see Results). Long-axis (a-axis) azimuth and dip of 50 clasts were measured as well as the length of the three axes of each clast used. The $a / b$ ratio ( $b$ : intermediate clast axis) of these clasts is $>1.7$ for $46-66 \%$ of the observations and $>$ 1.5 for $74-82 \%$. The data shown as Schmidt-net diagrams (lower hemisphere) were also used to calculate statistical parameters which define fabric strength and 'mean' orientation (normalised eigenvalues and eigenvectors, respectively). Results are shown in Table I. Diagrams and calculations were obtained using the Stereo ${ }^{\mathrm{tm}_{5}} 5.02$ program (McEachren, 1986). Mean clast size (mean b-axis length) and sorting (standard deviation) were also calculated for these units. 
TABLE I

Fabric analysis and additional sedimentary properties of three types of sediment; recent and fossil deposits of a scree slope near Veynes in the French Alps (see Fig. 7)

\begin{tabular}{|c|c|c|c|}
\hline & $\begin{array}{c}\text { Recent } \\
\text { 'aggreg.' flow }\end{array}$ & $\begin{array}{l}\text { Unit } \\
4 b\end{array}$ & $\begin{array}{l}\text { Unit } \\
12 b\end{array}$ \\
\hline $\begin{array}{l}\text { Tocal slope: } \\
\text { direction }\left(^{\circ}\right)\end{array}$ & 234 & $245-250$ & $245-250$ \\
\hline $\operatorname{dip}\left({ }^{\circ}\right)$ & 35 & $\sim 34$ & $32-33$ \\
\hline $\begin{array}{l}\text { mean lin.vector: } \\
\text { direction }\left(^{\circ}\right)\end{array}$ & 238.7 & 242.9 & 250.6 \\
\hline $\operatorname{dip}\left({ }^{\circ}\right)$ & 12.2 & 12.1 & 15.4 \\
\hline $\left.\mathrm{I}_{\text {iv }}\left({ }^{\circ}\right)^{1}\right)$ & 22.8 & $\sim 22$ & $\sim 17$ \\
\hline $\mathrm{S} 1^{2)}$ & 0.692 & 0.693 & 0.698 \\
\hline S2 & 0.241 & 0.222 & 0.173 \\
\hline S3 & 0.066 & 0.084 & 0.129 \\
\hline$r_{1}^{3)}$ & 1.05 & 1.14 & 1.39 \\
\hline$r_{2}$ & 1.29 & 0.97 & 0.29 \\
\hline $\mathrm{K}^{4)}$ & 0.82 & 1.18 & 4.76 \\
\hline spher.variance & 0.588 & 0.592 & 0.486 \\
\hline$\%$ 'plunging' 5) & 4 & 8 & 12 \\
\hline \% 'opposite' 6) & 30 & 30 & 28 \\
\hline $\begin{array}{l}\text { mean b-axis } \\
(\mathrm{mm})\end{array}$ & 12.7 & 14.2 & 16.5 \\
\hline sorting $(\mathrm{s})(\mathrm{mm})$ & 5.1 & 7.3 & 7.1 \\
\hline $\mathrm{N}$ & 50 & 50 & 50 \\
\hline
\end{tabular}

1) Imbrication index (see Hétu et al., 1995): $I_{i v}=P_{L}-V_{1} ; P_{L}=$ local slope dip value $\left(^{\circ}\right) \mathrm{V}_{1}=$ mean lineation vector $\operatorname{dip}\left({ }^{\circ}\right)$.

2) $S 1, S 2$, S3: normalised eigenvalues.

3) $r_{1}=\ln (\mathrm{S} 1 / \mathrm{S} 2)$ and $r_{2}=\ln (\mathrm{S} 2 / \mathrm{S} 3)$.

4) $K=r_{1} / r_{2}$ (see Woodcock, 1977).

5) \% 'plunging': percentage of clast a-axes dipping steeper than local slope dip (Hétu et al., 1995).

6) \% 'opposite': percentage of clast a-axes dipping opposite to local slope dip direction (Hétu et al., 1995).

\section{RESULTS}

\section{Observations on the 'active' slope}

\section{TRANSECT DESCRIPTION}

\section{Properties of the upper part}

The main element of this part of the slope is a well-developed slip plane consisting of fine grained material caused by dry grain flow (see Hétu et al., 1995). The inclination of this slope segment is $38-39^{\circ}$. Its width is about $3-5 \mathrm{~m}$ and its length is over $20 \mathrm{~m}$. Laterally, it is limited by ridges of open-

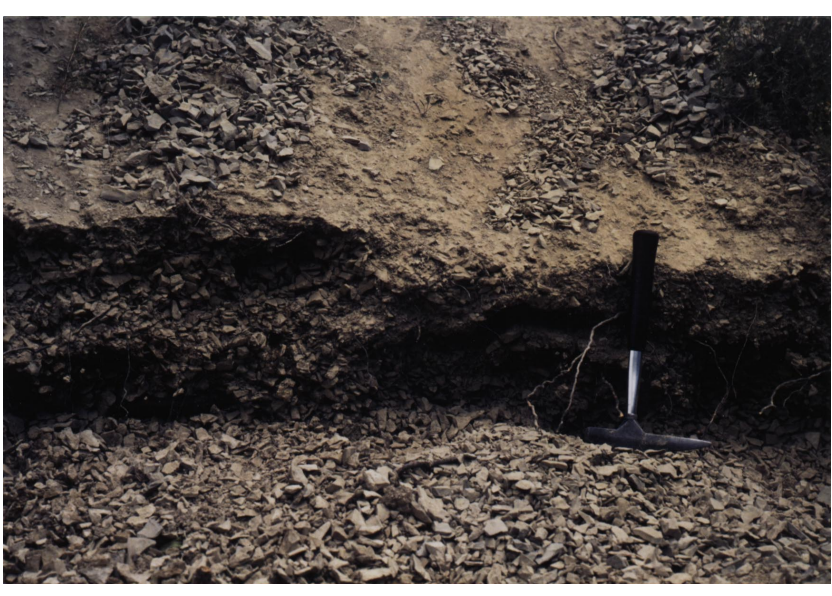

FIGURE 3. Sediments exposed in the right-hand part of the crosssection shown in Figure 2. Shaft of hammer: $27 \mathrm{~cm}$.

Vue des sédiments exposés dans la partie droite de la coupe décrite à la figure 2. Manche du marteau : $27 \mathrm{~cm}$.

work gravels of different clast size. Locally, shrubs are present on the downslope ends of these ridges. The parts of the slope immediately below the patches of vegetation are protected from the dry grain flows.

Most of the slip-plane surface is relatively smooth. Isolated small stones form miniature buttes (height generally < $1 \mathrm{~cm}$, and mostly $<0.5 \mathrm{~cm}$ ), separated by sandy to silty surfaces of low roughness. Locally these surfaces are covered by 'tails' of non-cohesive, often well-rounded aggregates (1$3 \mathrm{~mm}$ in diameter) accumulated upslope of the miniature buttes. These aggregates were formed by crumbling-away of the slip plane and by rain erosion of small earth pillars (see next paragraph). Macroscopic inspection of the aggregates showed that they consist of fine sand and silt grains with a calcareous cement. The 'tails' are instable deposits of granular material which can easily be mobilised by overland flow. Elsewhere, small and shallow (depth $<1 \mathrm{~cm}$ ) depressions are found on the slip plane.

If such a slip plane is exposed to weather influences over longer periods, its roughness increases, as is shown by the presence of many small earth pillars. The downslope side of these pillars is up to $4 \mathrm{~cm}$ high, while upslope height generally is a few millimetres, up to $1 \mathrm{~cm}$. The pillars, capped by a small clast, are caused by rain-splash erosion combined with transport by running water.

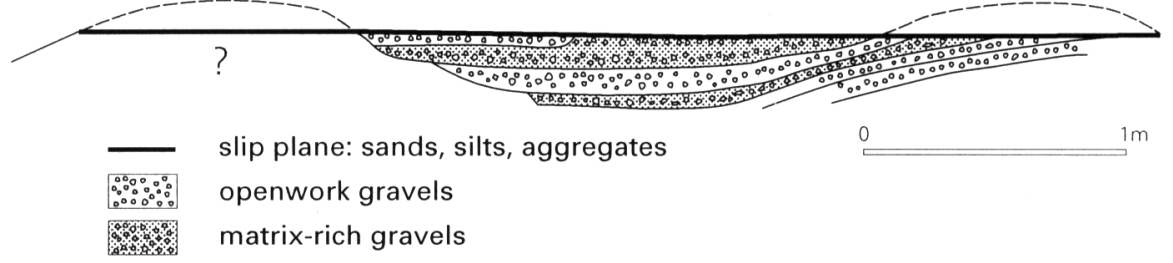

FIGURE 2. Schematic cross-section of superficial deposits at the lower end of a slip plane on the 'active' slope. See text for further explanation.

Stratigraphie de la partie inférieure d'un des plans de glissement du versant actif. Explications dans le texte. 
A cross-section was made near the downslope end of the slip plane in order to study the stratigraphy of the uppermost layers just below the slip surface (Figs. 2 and 3 ). The profile as a whole (Fig. 2) reveals a central depression flanked by two higher zones. Each of these three elements consists of an alternation of small dry grain flows and 'aggregate' flows. This whole system has been truncated, probably by a large dry grain flow or by a series of smaller ones, leaving the slip plane. Laterally, the development of both the slip plane and the grain flows is obstructed by shrubs. The part of the section shown in Figure 3 reveals an alternation of lenses of openwork clasts with layers of matrix-rich material in which well-rounded silty to sandy aggregates are abundant. Figure 3 also shows the surface of the lower part of the slip plane (visible just above the profile): it consists of small openwork lobes alternating with matrix-rich material. Below the slipplane surface characterised by a concentration of material < $5 \mathrm{~mm}$, a matrix-rich deposit occurs just within the upper 1-2 $\mathrm{cm}$ in the left-hand part of Figure 3, and over much greater depth more to the right. Protruding parts of the profile consist of lenses in which a sandy to silty matrix (generally with aggregates) causes the apparent cohesion. The lenses of matrix-rich material are interpreted as remnants of 'aggregate' flows (discussed below). Some of the vertical boundaries between the lenses are sharp, others are vague, the latter especially at the transition from the slip plane to the underlying material. Clast size is fairly uniform both in openwork lenses and in matrix-rich ones. Inverse grading occurs in lenses of matrix-rich material, but is not well developed.

\section{Properties of the lower part}

Immediately downslope of the profile just described, the mainly erosive upper slope segment gives way to a part in which accumulation is dominant. The accumulation pattern is determined by the location of shrubs. This leads to an alternation of elongated lobes and relatively deep depressions. The largest lobes are found below the large slip plane, and the most important hollows can be found directly downslope of large shrubs. Local relief within this zone is much larger than in the upper zone. It varies between 10 and 100 $\mathrm{cm}$, although generally it is in the range of $20-40 \mathrm{~cm}$. The lobes consist of the openwork deposits of individual grain flows. The general slope-angle value decreases to about $36^{\circ}$, but the frontal zones of lobes are steeper.

Clast size of the gravels on this part of the slope is related to topography: the coarsest material (mode: $5-10 \mathrm{~cm}$ ) is found in the depressions downslope of the vegetation. It accumulates by rockfall of clasts rolling down on the talus until they are deviated to such a depression. The dry-grainflow lobes contain somewhat finer material (mode: $3-5 \mathrm{~cm}$ ).

Sandy and silty materials are absent at the surface of this lower part of the transect, except very locally in small flows of restricted dimensions (width $30-70 \mathrm{~cm}$, thickness $3-5 \mathrm{~cm}$, length 3-10 m). These are the 'aggregate' flows mentioned previously. They originate on the slip plane which they prolong downslope. Like the coarse rockfall clasts, they may be deviated toward the depressions between the lobes of the dry grain flows. The section shown in Figures 2 and 3 proba-

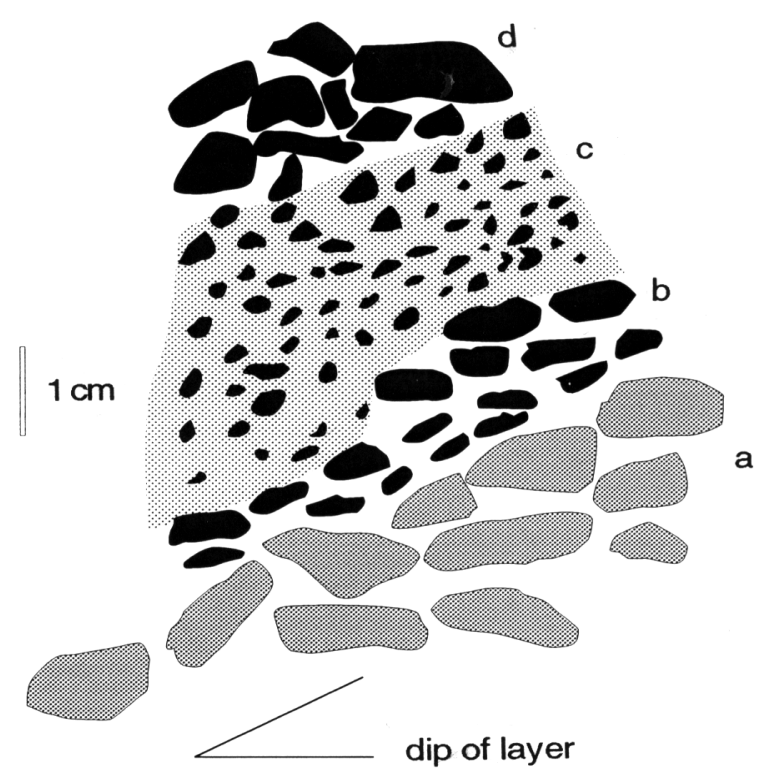

FIGURE 4. Schematic cross-section of an 'aggregate' flow, showing three characteristic sub-units. a: substrate (generally coarse, openwork gravel); b: basal layer of very fine, openwork gravel; aggregates almost absent; clasts oriented parallel to local slope direction; c: heterogeneous, matrix-rich material; matrix in form of rounded aggregates; very fine gravel $(<1 \mathrm{~cm})$; d: openwork gravel, imbricated.

Coupe schématique à travers une coulée d'agrégats montrant ses trois sous-unités caractéristiques. a: substrat grossier (cailloux à texture ouverte) sous la coulée; $b$ : couche basale de la coulée d'agrégats : petits graviers à texture ouverte ; agrégats peu abondants; éléments allongés parallèles à la pente ; c: cœur de la coulée : dépôt hétérométrique riche en matrice constituée presque entièrement d'agrégats limoneux de forme arrondie ; la fraction grossière est composée de sable et de petits graviers $(<1 \mathrm{~cm}) ; d$ : couche superficielle de la coulée : gravier openwork à forte imbrication (voir la fig. 5).

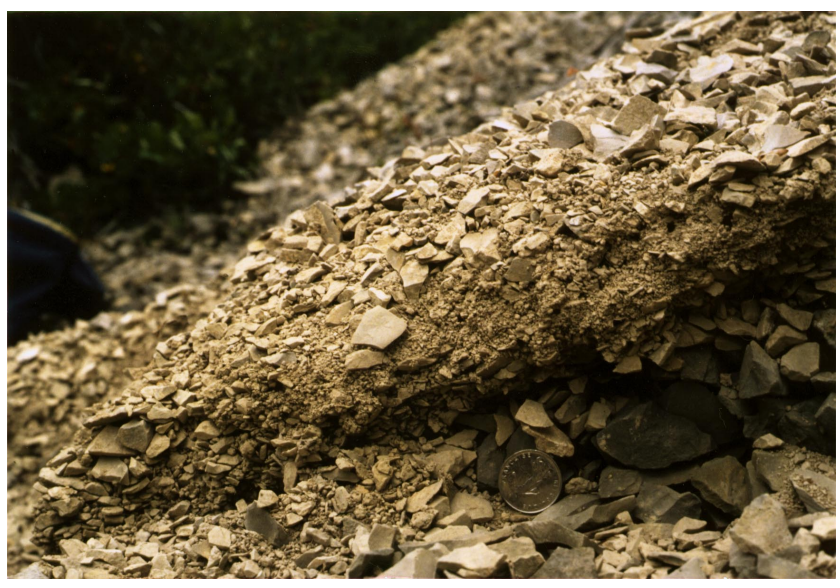

FIGURE 5. View of a recent 'aggregate' flow, found on the 'active' slope. Coin diameter: $29 \mathrm{~mm}$.

Structure interne d'une coulée d'agrégats récente trouvée à la surface du versant actif. Diamètre de la pièce de monnaie: $29 \mathrm{~mm}$. 
bly can be interpreted in this way: accumulation of small flows filling a depression between larger dry-grain-flow lobes, the whole being levelled-off by subsequent grain flow.

\section{TRANSPORT AND ACCUMULATION BY OVERLAND FLOW}

The spatial relationship between the 'aggregate' flows and the slip plane is seen as an important argument for the origin of these gravely and matrix-rich deposits. Overland flow on the 'active' slope is documented by traces of erosion on the slip plane. Runoff was artificially generated on the slip plane with a relatively small amount of water poured at its surface from a bottle. This runoff was able to entrain and transport sand and aggregates. The sedimentary properties of 'aggregate'-flow deposits are specified now before the development of such flows can be discussed.

The 'aggregate' flows show a characteristic internal structure. In upward direction the following sequence was observed (Figs. 4 and 5):

a) Substrate, formed by relatively coarse, open work gravels (dry-grain-flow deposit). In Figure 4 only the uppermost clasts of the substrate are shown.

b) Basal layer of very fine, openwork gravel (diameter 0.5-1 $\mathrm{cm}$; thickness $0.5-2 \mathrm{~cm}$ ), in which aggregates are practically lacking. The position of the clasts is more or less parallel to the local slope angle. The contact with the substrate is sharp: the elements of this basal layer do not penetrate into it. Its boundary with the overlying unit is fairly sharp as well.

c) Layer of heterogeneous material, in which abundant matrix in the form of rounded aggregates of silt to sand grains is found. The diameter of these aggregates is $0.5-3 \mathrm{~mm}$. The layer furthermore contains very fine gravels $(<1 \mathrm{~cm})$ showing some imbrication (subhorizontal position to upslope dip of the clasts) and a slight tendency to inverse grading. The thickness of this layer is about $2-5 \mathrm{~cm}$. A fabric analysis illustrates the orientation characteristics of the clasts in this material (Fig. 8a, Table I). The boundary with the overlying unit is sharp.

d) Layer of openwork gravels, diameter generally $1-2 \mathrm{~cm}$, but sometimes up to $5 \mathrm{~cm}$, sometimes showing strong imbrication. The material is coarsening upward. Thickness varies between 1 and $3 \mathrm{~cm}$.

Together, units (b), (c), and (d) form one 'aggregate' flow.

Observations of moving 'aggregate' flows are not available, but their development can be imagined as follows. During rainstorms of sufficient intensity (see Discussion), overland flow is generated on the fine-grained slip planes. Cohesionless aggregates together with fines detached by splash and traction force start moving. The liquid flowing on this slope of over $35^{\circ}$ erodes and transports an increasing mass of solids which causes the development of a flow with a relatively high density, rheologically transitional to grain flows as defined by Lowe, 1979. This flow in turn is able to detach and transport coarser clasts present along its flow

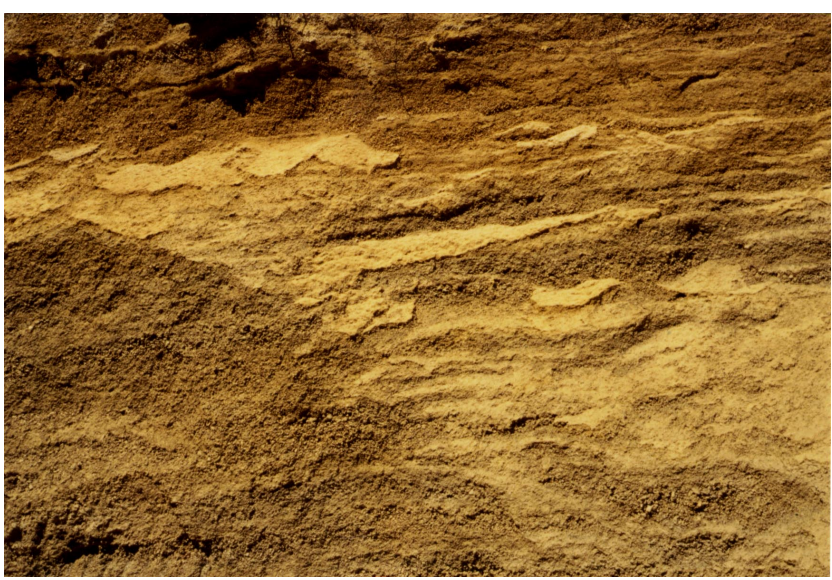

FIGURE 6. Fine-grained lenticular units exposed along the dip-perpendicular wall of the gravel pit near Veynes. The units, dipping approximately at angles of $35-40^{\circ}$, became exposed after heavy rainfall that occurred in January 1994. As explained in the text, they are interpreted as slip planes created by dry grain flows. Width of the section shown about $6 \mathrm{~m}$.

Gravière dans un éboulis stratifié relique près de Veynes. Unités lenticulaires composées de sédiments fins vues en coupe transversale, i.e. perpendiculaire à la direction du pendage, qui atteint ici $35-40^{\circ}$ Ces lits, mis en relief par les pluies intenses de janvier 1994, sont interprétés comme des plans de glissement de coulées sèches. Largeur de la zone photographiée: environ $6 \mathrm{~m}$.

path on the steep slope. During this stage the flow may obtain the character of a debris flow according to the model proposed by Takahashi $(1978,1980)$, in which the coarsest clasts concentrate in the front and at the surface of the flow. The result of this development is that these coarse elements progress more rapidly than the finer core of the flow. Layer (b) probably is such a concentration of gravels which moved more rapidly than the core (c). This means that it was deposited in front of the main flow mass, which was approaching slower, but which subsequently overran layer (b). On reaching a flatter part of the slope, frictional forces quickly stopped the movement. At the final stage of the event, matrix-free gravels (layer d) were deposited in front and partly on top of the already immobilised core. More diluted flow at the end of the event is thought to be responsible for this phase of rapid movement.

The presence of the aggregates in the flow deposits is not clearly understood. Manual tests revealed that the aggregates often were very resistent in attempts to destroy them. Probably the short transport distance together with the protectional cover by the top gravel layer are responsible for their survival in the flow deposits. Such aggregates are also found in many units of the relict deposits (see below). In the latter case non-aggregated silts may be present as well, which are sometimes laminated. Both types of silt deposits point to ultimate break-down of aggregates and to transport by running water. 
In conclusion, the analysis of the 'active' slope demonstrated two main elements. First, some processes work in close association and in a specific sequence. Dry grain flows leave fine-grained slip planes on which high-intensity rains cause overland flow, which may develop into 'aggregate' flows. In turn, after the development of a number of 'aggregate' flows the relatively smooth surface of the latter will promote further movement of dry grain flows.

Passing dry grain flows again may be erosive as is witnessed by the unconformity shown in Figures 2 and 3. Second, the sequential association of processes leaves a sequential association of facies which might be recognised within relict deposits. Furthermore, microtopography and isolated vegetation were found to be important with regard to the spatial pattern of deposits.

\section{Sections}

\section{GENERAL}

The main gravel-pit wall shows an irregular, lenticular pattern of beds consisting of different materials as will be described subsequently. An inspection of the gravel pit in June 1994 revealed that many thin, fine-grained units had become exposed, protruding several decimetres from the wall and steeply dipping (Fig. 6). The upper surfaces of these protruding layers are often plane, in which case they are interpreted as slip planes caused by dry grain flows by analogy with the slip planes found on the 'active' slope. The elements to be described are unequally distributed along the main wall: locally, lenses of matrix-rich material are virtually lacking, while elsewhere there is a much more even distribution of all main types.

The smaller longitudinal section reveals a relatively narrow range of dip angles $\left(28-32^{\circ}\right)$ and an irregular alternation of several types of beds, in which textures and fabrics may differ very much. The main sediment types found in the transverse section can be recognised again.

\section{TRANSVERSE SECTION}

The transverse section shown in Figure 7 is a part of the main wall of the pit (Fig. 1b). An impression of the physiognomy of the wall can be obtained from Figure 6 . The description follows a chronological order, starting with the oldest unit visible in this section. The numbering used in the text corresponds to that of Figure 7.

1. Coarse, openwork clasts. Well-developed coarseningupward (= inverse) grading. Modal particle size 6-8 cm; near the bottom $<5 \mathrm{~cm}$; near the top 6-8 cm. Dry grain flow.

2. Fine gravels (mode: $1 \mathrm{~cm}$ ) in matrix consisting of fine, silty aggregates (modal diameter $1 \mathrm{~mm}$ ). At lower boundary
FIGURE 7. Detailed survey of a part of the transverse (dip-perpendicular) section of the gravel pit.

Stratigraphie détaillée d'une partie de l'éboulis relique vue en coupe transversale (perpendiculaire au pendage).

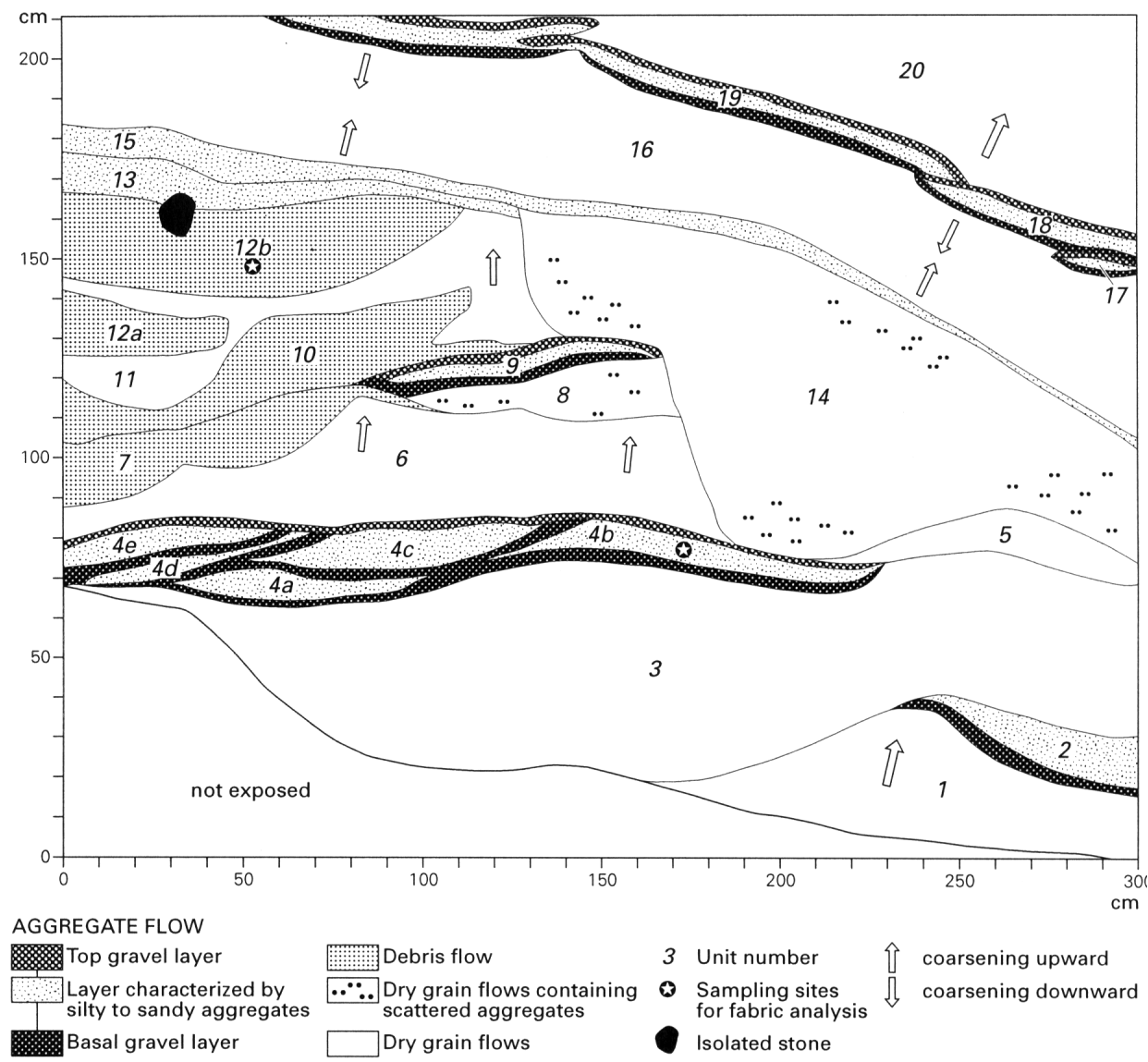


a thin layer $(1-2 \mathrm{~cm})$ of openwork, very fine gravels $(<1 \mathrm{~cm})$ is present. 'Aggregate' flow, filling a depression.

3. Large layer of homogeneous, openwork gravels. Mode: 3-4 cm. No grading visible. Dry grain flow?

4. Complex unit consisting of several lenses each showing an identical internal structure:

- at the base: very fine, openwork gravel $(0.5-1 \mathrm{~cm})$; the thickness of this 'sole' is $0.5-2 \mathrm{~cm}$;

- central part: mixture of very fine gravel (modal size about $1 \mathrm{~cm}$ ) and silty to sandy aggregates (diameter 0.5-3 mm). Gravels mainly matrix supported. Layer more compacted than the aggregate-rich layers of the recent 'aggregate' flows found on the 'active' slope (Fig. 4, layer c), probably due to post-sedimentary infiltration of silt-rich water and to the loading effect of overlaying deposits. Thickness up to about $10 \mathrm{~cm}$. Clast orientation is mainly parallel to the slope; sometimes a well-developed imbrication exists. Figure $8 b$ shows a fabric analysis for the central part of subunit $4 \mathrm{~b}$ (see also Table I);

- at the top: thin layer of gravels, somewhat coarser than in central part or basal layer - but generally $<3 \mathrm{~cm}$. Thickness $1-3 \mathrm{~cm}$. At the top of sub-unit $4 \mathrm{e}$, its dip was measured at $34^{\circ}$.

The dimensions of the lenses present in unit 4 correspond to those of the 'aggregate' flows on the 'active' slope. The complex is interpreted as a series of 'aggregate' flows.

5. Lens of openwork gravel in which a certain amount of aggregates were found, dispersed within the mass. Modal clast size: $3-6 \mathrm{~cm}$. Probably a dry grain flow which eroded an 'aggregate' flow during its course.

6. Fine gravel in openwork configuration. Mode: $2-3 \mathrm{~cm}$. Locally, inverse grading. Dry grain flow, deposited after sliding on top of the finer-grained 'aggregate' flows, the surface of which was transformed into a slip plane.

7. Lens of massif, matrix-rich material. The silty matrix does not consist of aggregates. A basal layer ('sole') of fine openwork gravels is lacking. Debris flow.

8. Lens of openwork gravels showing a large number of relatively wide pores. Clast mode: $3-5 \mathrm{~cm}$. Some aggregates are present, spread throughout the unit. Probably a deposit of a dry grain flow in which infiltrated overland flow subsequently caused the presence of apparently resistant aggregates.

9. 'Aggregate' flow with basal layer of fine, openwork gravel. Locally, a silty matrix is observed which is caused by post-sedimentary infiltration of silt-rich water. The aggregate structure can sometimes be recognised within this matrix.

10. Mixture of fine gravels $(3-5 \mathrm{~cm})$ and aggregates within a fairly abundant matrix. The material is slightly compacted. A basal 'sole' of very fine openwork gravel is absent. Clasts do not show a preferred orientation. Probably a debris flow.

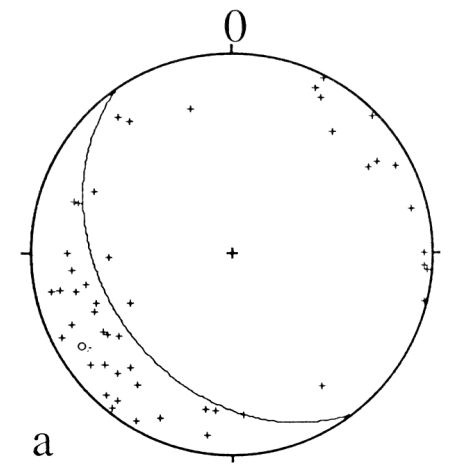

FIGURE 8. Schmidt-net (equal area, lower hemisphere) diagrams showing fabrics of three sedimentary units. Great circles indicate local slope direction and dip (a), and position of unit $4 \mathrm{~b}$ and 12 (b and c, respectively). mlv: mean lineation vector. a: central part of fresh 'aggregate' flow as found on the 'active' slope (see Fig. 5); b: central part of 'aggregate' flow within the fossil deposits. Unit 4b; position of the sampling site indicated in Figure 7; c: debris-flow material; unit 12b (see Fig. 7)

Orientation et inclinaison du grand axe des éléments représentés sur des stéréogrammes de Schmidt (aire égale; hémisphère inférieure). Le grand arc de cercle représente pour a : l'orientation et l'inclinaison $d u$ versant au site des mesures et pour b et $c:$ la direction et le pendage des unités $4 b$ et $12 b$.; m/v : grand vecteur moyen (tabl. I). ; a: partie centrale d'une coulée d'agrégats actuelle à la surface du versant actif (voir fig. 5); $b$ : partie centrale d'une coulée d'agrégats fossile (unité 4b); c: lave boueuse fossile (unité12b). Pour b et c: localisation des sites d'échantillonnage à la figure 7.

11. Lenses of more or less homogeneous openwork gravel. Mode: $3-5 \mathrm{~cm}$ (left) and 4-6 cm (right). Locally, inverse grading can be found. Material properties point to dry grain flow, but irregular lens form hardly supports this interpretation.

12. Massif lenses of matrix-rich, clast-supported material. No aggregates, no basal 'sole' of very fine gravels. Some clasts are steeply imbricated in upslope direction. 12a and $12 \mathrm{~b}$ : debris flows. Fabric data for $12 \mathrm{~b}$ are shown in Figure $8 \mathrm{c}$ and Table I.

13. Thin layer of fine gravels mixed with aggregates (diameter 1-3 mm). Probably the core of an 'aggregate' flow. 
FIGURE 9. Detailed survey of a part of the longitudinal section of the gravel pit.

Stratigraphie détailée d'une partie de l'éboulis relique vue en coupe sagittale (parallèle au pendage).

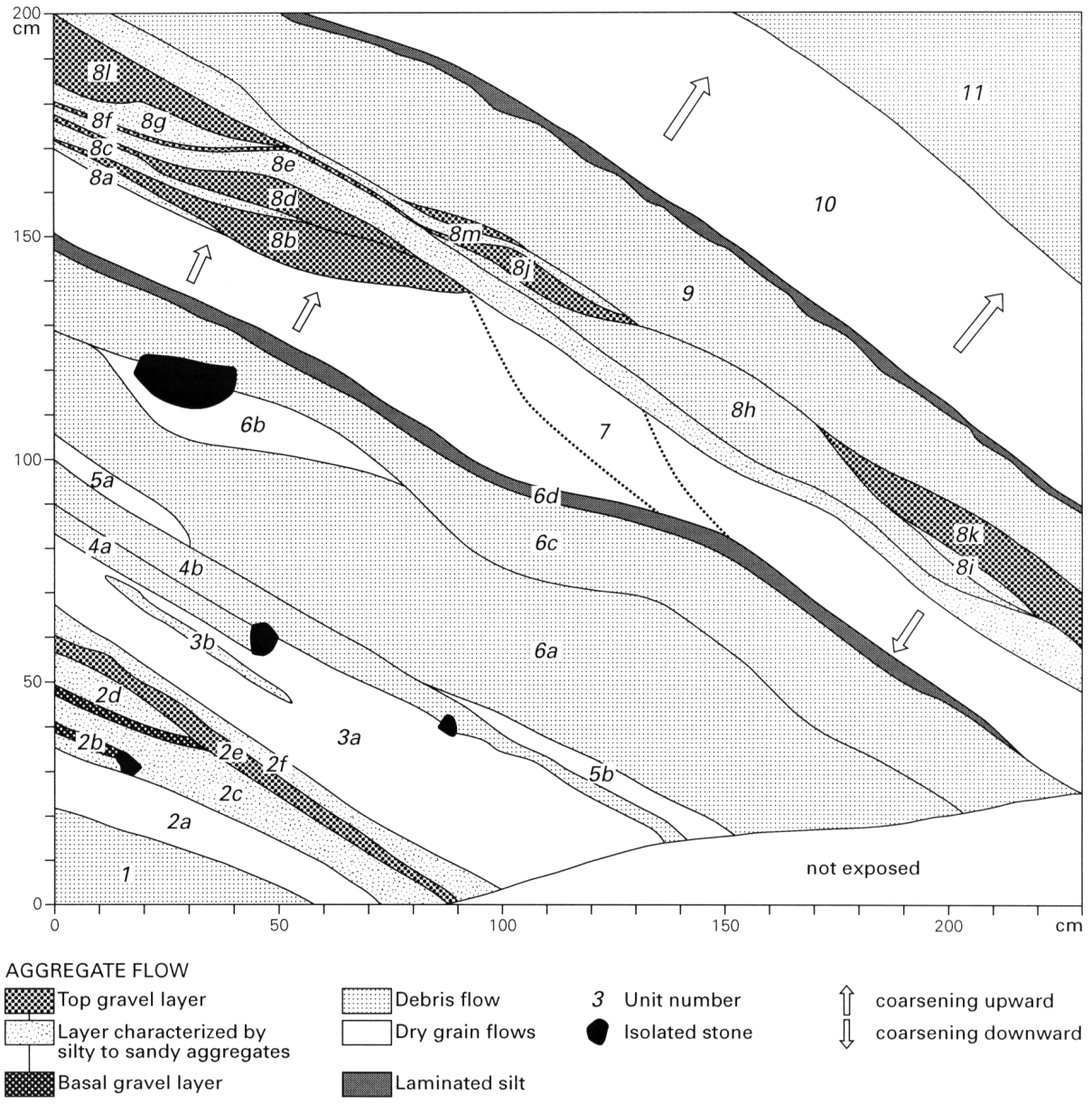

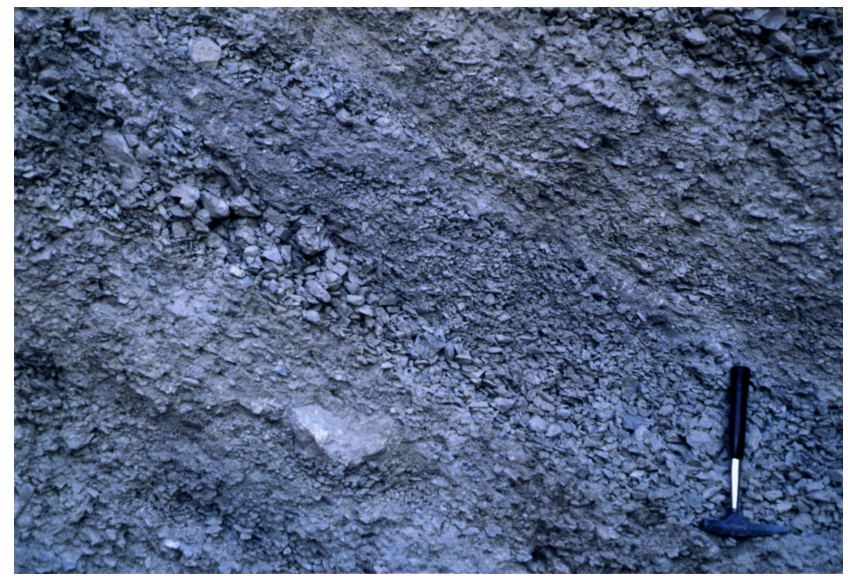

FIGURE 10. Part of the section shown in Figure 9 (from unit 4 in lower left corner to unit 10 in upper right part).

Vue d'une partie de la coupe décrite à la figure 9 (de l'unité 4 dans le coin inférieur gauche à l'unité 10 dans le coin supérieur droit).
14. Large unit, consisting of coarse, openwork gravels Mode: $5-8 \mathrm{~cm}$. Deposited within a large gully cut through units $6-9,11,13$ and probably unit 12 as well. The lateral contact with these units is accentuated by stones in nearly vertical position, forced against the wall of the former gully. Spread within the whole unit, some large aggregates (diameter 2-3 $\mathrm{mm}$ ) are found. Deposit of one or more large (dry) grainflow(s) within a gully which latter was probably formed during an extreme rainfall event.

15. Thin layer of massif, matrix-rich material. Aggregates are found at top and bottom of the layer, but they are lacking in the central parts. The layer is strongly compacted. A basal 'sole' of fine gravel is absent. The top of the layer shows a dip of $32-33^{\circ}$. A proper interpretation of this unit is not possible: it seems much too wide for an 'aggregate' flow.

16. Openwork gravels. Mode: $3-5 \mathrm{~cm}$ in the central parts, passing to 1-2 cm, both upward and downward, thus revealing two directions of grading as indicated in Figure 7. Probably a dry grain flow. 
17-18-19. Lenses of matrix-rich material. Clast mode: 1 $\mathrm{cm}$. Above as well as below the central parts, large amounts of aggregates exist. Basal 'sole' of very fine openwork gravels (thickness 2-3 cm) well developed below each of the lenses. 'Aggregate' flows, the pores of the central parts of which were filled in by subsequent illuviation.

20. Layer of openwork gravels, showing a slight inverse grading. Mode: $1-2 \mathrm{~cm}$ at the contact with unit 19, passing to $3-5 \mathrm{~cm}$ near the top. Dry grain flow which like unit 6 moved sliding on top of a complex of 'aggregate' flows.

\section{LONGITUDINAL SECTION}

The position of the longitudinal section shown in Fig. 9 is indicated in Figure 1b. A part of this surface is also depicted in Figure 10. It is emphasised that many of the sedimentary units described are lenticular forms of restricted dimensions, which indicates that the direction of this section is only approximately parallel to the dip of the layers.

1. Layer of gravely, matrix-rich material. Gravels up to 8 $\mathrm{cm}$ are found. Silty to loamy matrix. Debris flow.

2. Series of small, superposed 'aggregate' flows, deposited on top of a small dry grain flow (2a). Fine-grained basal layers (aggregates of 1-2 mm and very fine gravels, generally $<2 \mathrm{~cm}$ ) alternate with somewhat coarser openwork gravel layers in which clast size is between 2 and $6 \mathrm{~cm}$. The fine-grained layers may be accompanied by a thin 'sole' of very fine openwork gravels $(2 \mathrm{c}$ and $2 \mathrm{~d}$ ). This set of sub-units can be followed along the section wall over several metres.

3. Lens of openwork gravels (3a). In its upslope part, the material is somewhat finer $(2-3 \mathrm{~cm})$ than in the downslope part $(5-7 \mathrm{~cm})$. Sub-unit $3 \mathrm{~b}$ is a small deposit of silty material (thickness 1-2 cm), probably due to a small 'aggregate' flow. Perhaps two grain flow events are present, the boundary between which is only visible where the 'aggregate' flow occurs.

4. Heterogeneous material, containing a silty matrix. Probably debris-flow deposits. Sub-unit 4 a can be followed only over a short distance: it ends at a relatively large stone. The material contains many clasts of up to $5-8 \mathrm{~cm}$. Sub-unit $4 \mathrm{~b}$ consists, apart from the matrix, of fine gravels $(1-2 \mathrm{~cm})$. Some of the clasts are steeply dipping upslope. The base of this layer is formed by very fine openwork gravels (thickness $0.5-2 \mathrm{~cm}$ ). The material does not penetrate into the coarser gravels of unit 3 .

$5 \mathrm{a}$ and $\mathrm{b}$. Thin lenses of openwork gravels, clast size 3-5 $\mathrm{cm}$. Probably the eroded remnants of a thin (dry) grain flow.

6. Massive deposits of very heterogeneous material. Fine to coarse gravels, clast supported, within a silty matrix. Two debris-flow deposits (6a and $6 \mathrm{c}$ ), locally separated by a lens of openwork gravels caused by a dry grain flow (6b). Within the thinner, upslope parts (left side), clasts are oriented subparallel to the dip of the layer, while the thicker parts downslope show a well-developed imbrication, clasts dipping in upslope direction. The thinner parts represent transit zones, as they existed within the moving debris flow, whereas the imbrication within the thicker parts points to checking of the moving mass, as in the terminal lobes of debris flows. This is especially clear within the subhorizontal parts of sub-units $6 \mathrm{a}$ and $6 \mathrm{c}$. The top of sub-unit $6 \mathrm{c}$ is formed by a thin level where laminated silts are present, filling the space between clasts over a thickness of 1-3 cm (sub-unit $6 \mathrm{~d})$. The discontinuous laminae are subhorizontal in all parts, sometimes more or less saucer-shaped, dependant on the form of the space between the clasts. They probably are deposited from infiltrating silt-rich water, after the deposition of the original debris flow.

7. Openwork gravels, showing well-developed inverse grading in its upslope (left-hand) part. Grading features are lacking within the central part, while the downslope part reveals a normal grading of the clasts. A dry grain flow with a terminal lobe deposited on top of the subhorizontal surface of sub-unit $6 \mathrm{c}$. The material deposited downslope of the lobe probably represents a collapsed part of the front, causing the normal grading mentioned.

8. Series of 'aggregate'-flow deposits (8a-8m), interrupted by a small debris-flow deposit (8h). The deposits show the elements observed in the recent 'aggregate' flows found on the 'active' slope, though not everywhere all parts of the sequence are preserved. Generally speaking, the main constituent is a layer of fine gravels within a sandy to silty matrix (sub-units 8a, c, e, g, m). The corresponding 'sole' of very fine, openwork gravels is however only very locally found. The layers of matrix-rich material are covered by thin layers of strongly imbricated openwork gravels (mode 2-3 cm, clasts dipping upslope). These layers are continued downslope by lenses of the same openwork gravels, deposited in front of the finer material. Rapid infiltration (in front of the fine-grained deposits) of the water that was propulsing the coarse load limited the accumulation zone of the latter to the fringe of the finer deposits (sub-units $8 b, d, j, k, I)$. Subunit $8 \mathrm{~h}$ is much more heterogeneous than the matrix-containing layers of the system 8 as a whole. Fine gravels are predominant in $8 \mathrm{~h}$, but gravels $>2 \mathrm{~cm}$ are present in small quantities. Matrix is fairly abundant, but leaving many open pores. Clasts show well-developed imbrication. Probably a deposit from a relatively fluid debris flow, which could maintain itself because of the presence of the relatively impermeable material of sub-unit 8 e.

9. Massive deposit of heterogeneous gravels (clasts up to $10 \mathrm{~cm}$ ) in a very abundant silty to sandy matrix. Debris flow. Clasts show well-developed imbrication, pointing to the checking of the progressing flow. Within the upper $2-4 \mathrm{~cm}$ of this unit finely laminated silts are found, filling small depressions at the surface of the debris flow as well as larger pores between clasts below this surface. Laminae are subhorizontal, which (as for sub-unit 6d) points to percolation of silt-rich water after deposition of the debris flow.

10. Layer of openwork gravels showing well-developed inverse grading. Deposit of a dry grain flow. 
11. Massive deposit of heterogeneous, matrix-rich gravels. Strong imbrication as within unit 9, pointing to checking of the moving material. Debris-flow deposit.

For some of the units the interpretation remains uncertain because their properties are not sufficiently diagnostic. The most important cases will be mentioned briefly. Unit 3 of the transverse section (lacking vertical grading) might be deposited by single particle rock fall but decisive diagnostic criteria were not found. Unit 14 of the transverse section, confined within a gully and almost lacking fine fractions, could be a sieve deposit (Hooke, 1967). At the place of unit 14 there are however no signs of the required discontinuity in the sediment transport capacity (Hooke, 1967; Nemec and Postma, 1993). The horizontal dimensions of unit 15 are different from those generally found for 'aggregate' flows. Here, post sedimentary percolating water may have obliterated a structure like that of units 17-19. Solifluction might have deposited unit 6 of the longitudinal section but the characteristics described by Francou (1988) or Bertran et al. (1993) were not found.

Effects of reworking after the inititial deposition of a sediment should be considered when interpreting sedimentary properties with regard to depositional processes. Reworking by different types of creep undoubtedly must have affected a part of the deposits. Their influence generally is to attenuate clast fabrics (Hétu and Vandelac, 1989; Pérez, 1990; Hétu, 1995) but not a fundamental rearrangement of the sediment as a whole. Theoretically, snow creep is able to rework debris-flow deposits, ultimately leading to the development of stone-banked lobes (Francou, 1989, 1990) but no unit revealed the proper diagnostic properties described by Francou. The probability of linear elements caused by snow creep (Hétu and Vandelac, 1989:399) being exposed in the section seems very small. It is assumed therefore that the influence of reworking on material properties can be neglected.

\section{DISCUSSION}

\section{DIFFERENCES BETWEEN 'ACTIVE-SLOPE' DEPOSITS AND SEDIMENTS FOUND IN SECTIONS}

A number of differences were found between the sediments of the 'active' slope and those of the main body of stratified slope deposits. The following points must be mentioned here.

1) The fine-grained layers of the relict deposits interpreted as 'aggregate' flows are more compacted than the central part of the present-day 'aggregate'-flow deposits. Increased compaction is seen as caused mainly by two factors. First, continuing accumulation caused a weight effect resulting in increased internal pressure. Second, subsurface flow locally caused illuviation of finer particles, especially where decreasing hydraulic conductivity occurred. The influence of subsurface flow is illustrated by the irregular distribution of sandy and silty material in several sedimentary units and by the local presence of laminated silts.
2) Dip angles of sedimentary units in the sections are relatively low when compared to the situation on the 'active' slope. Furthermore, dip angles obtained from the longitudinal section are $28-32^{\circ}$ while those from the transverse section are $32-34^{\circ}$. Several possible explanations can be considered.

-The values obtained may differ from the real dip of the beds because the direction of the section does not coincide with the true dip direction of the beds (longitudinal section) or is not exactly perpendicular to true dip (transverse section). Moreover, measurement was difficult in the case of units $4 \mathrm{e}$ and 15 of the transverse section because only small parts of their surface were exposed. An underestimation of dip angles will be the result. Support for this explanation is obtained from the observation of relatively large, steeply dipping planes extruding from the main pit wall.

- Large dry grain flows, once mobilised, are able to stay in motion on slopes much less than $35^{\circ}$, as was seen by Wasson (1979) who reported that flows came to rest on slopes of only $15-20^{\circ}$. Furthermore, the dip values mentioned in the present study are close to those given in relation with dry-grain-flow deposits by Van Steijn et al., 1995.

-A part of the matrix-free clast flows observed at the site near Veynes may have come down on snow- or ice-covered slopes or as frost-coated clast flows (as described by Hétu et al., 1994; Hétu,1995; Van Steijn et al., 1995). The first and third of the possibilities given are most likely to apply: inaccurate estimates of dip values cannot be excluded, as was explained, and locally gentler slopes occur as shown in Figure 9 (units 6 and 8). Furthermore, periglacial or at least cold conditions necessary for the third explanation to be valid existed in the South of France at least until the final phase of the last glaciation (Jorda, 1988; Gautier, 1991; 1992; Texier and Bertran, 1993).

3) Debris-flow traces are common within the relict deposits but are lacking on the 'active' slope. This probably means that the material presently available at the slope surface does not contain a quantity of fines (sand and finer) sufficient for the development of debris flows having dimensions like those found in the sections. An alternative explanation would be that in the recent past debris-flow triggering weather conditions (i.e. rainstorms reaching the threshold value of intensity and duration) did not occur.

\section{SEDIMENT SEQUENCES AND ENVIRONMENTAL CONDITIONS DURING THE DEVELOPMENT OF THE DEPOSITS}

Figures 7 and 9 show sequences of predominant drygrain flow activity, or of debris flows, or of 'aggregate'-flow formation. These sequences indicate a succession of sets of environmental conditions, climatic factors included. Although other processes may have been involved in the deposition of some of the units described (single-particle rock fall, solifluction), their significance appears to be restricted. Figures 7 
and 9 also reveal a close association between two members of the facies types found: deposits of the 'aggregate' flows are very often found on top of those of the dry grain flows. Within Figure 7 the sequence of 'aggregate' flows on top of dry grain-flow deposits is visible four times: unit 2 on 1; complex unit 4 on $3 ; 9$ on $8 ; 17-18-19$ on 16. The same combination is present in Figure 9: complex unit 8 on 7, and perhaps sub-units $2 b-2 f$ on $2 a$. The relationship can be explained by the following sequence of events.

a) During an initial phase, one or more dry grain flows cause the development of a fine-grained slip plane, essential for overland-flow initiation.

b) Aggregates and other small granular material are detached from and/or transported along the slip plane by splash and overland flow during high-intensity (but not exceptional) rainstorms. The rain erosion increases the roughness of the slip plane (miniature earth pillars), and small clasts coming from the cliff zone, as well as from the earth pillars form small gravel accumulations on the slip plane (Fig. 3).

c) During a rainstorm of exceptional intensity/duration combination, the material prepared by splash and small-scale overland transport is mobilised to form a flow mainly containing aggregates but also small gravels. As stated, initiation of these 'aggregate' flows is only possible on the slip plane, because it is the only zone on the scree slope where overland flow can develop. After reaching the downslope end of the slip plane the 'aggregate' flow continues its course on the openwork material of the corresponding dry grain flows. The 'aggregate' flows tend to be deflected laterally toward the depressions between the lobes of the dry grain flows, thus contributing to the smoothing of the talus surface.

d) In turn, subsequent dry grain flows reach lower positions on the slope if they can move on a surface smoothed by an episode of 'aggregate'-flow activity. Then, the cycle b d may start again.

Thus, the combination of dry grain flow and 'aggregate' flow is an indication of periods of mainly dry weather (drygrain-flow activity) interrupted by short spells of overlandflow occurrence due to rainfall at various levels of intensity (only the highest magnitude rainstorms causing 'aggregate' flows). Critical rainfall events must have been more frequent when complexes of 'aggregate' flows developed like the complex unit 4 of Figure 7, or unit 8 of Figure 9. The length of the different periods can not be estimated from the available evidence because no datings are available. For dry conditions, periods of some decades to a century are perhaps a more acceptable guess than longer time intervals. Rainy episodes might still have been shorter. Thus, the variability of meteorological conditions evoked points to fluctuations within one and the same climate rather than to a succession of more distinctly differing climates.

Present-day observations show that dry grain flows may occur under a wide range of environmental conditions. Requirements are (1) the availability of large amounts of cohesionless debris accumulating on a steep slope, (2) lithological conditions allowing the production of relatively small clasts, and (3) absence of a dense vegetation cover. Comparison with a scree slope near Bélesten (French Pyrénées) studied by Hétu et al., 1995, in which dry grain flows are the essential constituent underscores the importance of lithological properties. The deposit as a whole contains very little sand-sized material or finer (cf. Hétu et al., 1995, p. 183), due to bedrock (a massif Cretaceous limestone). As indicated, the deposits near Veynes are derived in part from marls and marly limestone. Other examples of this lithological influence are mentioned in Hétu et al. (1995).

Like dry grain flows, 'aggregate' flows will be an azonal process because overland flow occurs under a wide range of climatic conditions. The observations on the 'active' slope showed that permafrost or seasonally frozen ground are not required for the initiaton of 'aggregate' flows. As for debris flows, high-intensity rainfall seems to be an essential factor, but estimates of intensities needed are still lacking for this newly recognised feature.

The occurrence of debris flows within a proper geomorphological setting is controlled by meteorological conditions together with the availability of fine weathering products which latter depends mainly on bedrock properties. The precipitation conditions for 'hill-slope' debris flows occurring in morphological systems like that discussed here are somewhat better known than for the other rapid transfer processes on slopes (Caine, 1980; Blijenberg, 1993). Highintensity rain storms triggering debris flows presently develop in this region almost exclusively during summer and autumn. Intensities of about $100 \mathrm{~mm} \mathrm{~h}^{-1}$ during some $5 \mathrm{~min}$ utes may cause debris flows of the dimensions that were found in the sections of the gravel pit near Veynes (Van Steijn, 1991), values that should be seen as an order-ofmagnitude estimate. Under periglacial conditions (especially permafrost), less precipitation is needed, as shown in several Scandinavian studies (see Larsson, 1982; Rapp and Nyberg, 1988). The existence of cold conditions in the south of France at the end of the last glaciation was mentioned already but the distribution of permafrost during this period and the duration of its decay at the transition toward the Holocene are not well known. Thus, the influence of frozen ground on the triggering conditions for debris flows or 'aggregate' flows cannot be specified.

The degree of vegetation cover during the development of the scree accumulation near Veynes is another unknown element. Within the deposits no macroscopically visible traces of the contemporary (or younger) vegetation were found. However, this does not mean that any influence of vegetation should be denied. Both sections described in detail, and certainly the main gravel-pit wall as a whole show many traces of shifts within the accumulation zones for the different processes. As demonstrated for the 'active' slope, the position of accumulation zones at a certain moment is strongly influenced by local topography and/or by vegetation patches. Both types of obstacles determine the local direction of transport and accumulation. Studies by Gautier, 1991 
and 1992 point to the presence of vegetation patches or locally open forest on the slopes in the Buëch region at the transition from the Late Glacial to the Holocene. A provisional conclusion therefore is that scree slopes on which stratified slope deposits developed like those described here were not necessarily completely free of vegetation.

Most of the processes involved appeared to be azonal. The consequence of this statement is that stratified slope deposits like those described in the present study cannot be used for the recognition of environmental conditions during their development without additional evidence. However, for mid-latitude situations like in the south of France, a periglacial climate is the only one to combine two important factors (see Hétu et al., 1995). It favours the production of large quantities of debris and it prevents the development of a dense vegetation cover. Thus, apart from the influence of lithology, only cold-environment conditions are suitable for the development of the range of sediment types found in these stratified slope deposits, however without requiring permafrost. In this part of France a poor vegetation cover extended well beyond the Late Glacial-Holocene limit into the Holocene (Jorda, 1988; Gautier, 1991; 1992). The latter statement means that without proper dating the development of scree slopes cannot be restricted here to Pleistocene periods.

\section{CONCLUSIONS}

A detailed analysis of sections present in a gravel pit near Veynes (Préalpes du Sud, France) showed that three types of transport processes were involved in the development of the deposit. Main constituent are deposits from dry grain flows. Accumulation by this process was interrupted several times, either by debris-flow activity, or by events of what the authors call 'aggregate' flows.

'Aggregate' flows are caused by rain-generated overland flow. This conclusion was obtained as a result of studying phenomena on the present-day surface of the scree slope in which the gravel pit was opened. Characteristically, a deposit of an 'aggregate' flow consists of three components: (1) a top layer (thickness $1-3 \mathrm{~cm}$ ) of fine openwork gravels, often strongly imbricated, (2) a central part (thickness 2-5 $\mathrm{cm}$ ) of heterogeneous material with abundant matrix, mainly formed by sandy to silty aggregates (diameter $0.5-3 \mathrm{~mm}$ ) together with very fine gravels (diameter $<2 \mathrm{~cm}$ ), and (3) a basal layer (thickness $0.5-2 \mathrm{~cm}$ ) of fine, openwork gravels, in which aggregates are rare and in which clast position is more or less parallel to the local slope angle. 'Aggregate' flows are interpreted as related to debris flows, but different from the latter in rheological behaviour in the sense of being transitional to grain flow.

It was found that episodes of 'aggregate'-flow activity only occurred subsequently to dry-grain-flow activity, because the fine-grained slip planes from the latter are essential for the development of overland flow. In turn, a series of 'aggregate' flows promoted new events of dry grain flow by smoothing the scree surface. In this way, a chain of processes existed, from time to time interrupted by debris flows.
Dry grain flow and overland flow are azonal processes. Their predominance in the deposits studied means that in this case process reconstruction alone does not allow the recognition of periglacial conditions, existing during their development. However, in the south of France only a periglacial environment could provide a combination of suitable conditions: high production of coarser and finer debris, and sparse vegetation.

A more general conclusion has to be, that a climate signal may be present within stratified slope deposits, though their climatic interpretation is complicated by the azonal character of some of the processes involved and by the interference with local conditions (lithology, microtopography, vegetation). This implies that stratified slope deposits cannot be used as diagnostic for periglacial conditions without restrictions.

\section{ACKNOWLEDGEMENTS}

Professor Hugh French is thanked for his comments on an earlier draught of the manuscript. Referees MarieFrançoise André and Jean-Pierre Texier are greatfully acknowledged because their remarks improved the contents of the article. Financial support by the Natural Sciences and Engineering Research Council of Canada is gratefully acknowledged by the second author.

\section{REFERENCES}

Bertran, P., Coutard, J.-P., Ozouf, J.-C. and Texier, J.-P., 1992. Données nouvelles sur l'origine du litage des grèzes: implications paléoclimatiques. Géographie physique et Quaternaire, 46: 97112.

Bertran, P., Francou, B. and Pech, P., 1993. Stratogenèse associée à la dynamique des coulées à front pierreux en milieu alpin, La Mortice, Alpes méridionales, France. Géographie physique et Quaternaire, 47: 93-100.

Blijenberg, H.M., 1993. Results of debris flow investigations on the recent time scale, p. 609-650. In J.-C. Flageollet, ed., Temporal Occurrence and Forecasting of Landslides in the European Community. Programme EPOCH, Contract 90 0025, Final Report, Part II.

Caine, N.,1980. The rainfall intensity-duration control of shallow landslides and debris flows. Geografiska Annaler, 62A: 23-27.

Debelmas, J., 1974. Géologie de la France. Masson, Paris, 540 p.

Descroix, L., 1989. La mesure de l'érosion actuelle dans les terres noires des Préalpes du Sud: recherches sur petites parcelles expérimentales. Bulletin du Laboratoire rhodanien de Géomorphologie (Lyon), 23-24:11-26.

Francou, B., 1989. La stratogenèse dans les formations de pente soumises à l'action du gel. Bulletin de l'Association française pour l'étude du Quaternaire, 1989-4: 185-199.

1990. Stratification mechanisms in slope deposits in high subequatorial mountains. Permafrost and Periglacial Processes, 1: 249-263.

French, H.M.,1976. The Periglacial Environment. Longman, London, $309 \mathrm{p}$. 
Gaussen, H., 1970. Précipitations, températures et végetation des Alpes occidentales. Veröffentlichungen, Geobotanisches Institut Zürich, 1970: 44-57.

Gautier, E., 1991. Essai d'interprétation dynamique de la phase d'accumulation holocène principale du bassin du Buëch (Alpes du Sud). Physio-Géo, Travaux du Laboratoire de Géographie physique Pierre Birot, Meudon, 22-23: 29-36.

1992. Recherches sur la morphologie et la dynamique fluviales dans le bassin du Buëch (Alpes du Sud). Thèse de Doctorat de Géographie, Université de Paris X - Nanterre, 439 p.

Hétu, B., 1991. Éboulis stratifiés actifs près de Manche-d'Epée, Gaspésie (Québec, Canada). Zeitschrift für Geomorphologie, Neue Folge, 35: 439-461.

1995. Le litage des éboulis stratifiés cryonivaux en Gaspésie (Québec, Canada): rôle de la sédimentation nivéo-éolienne et des transits supranivaux. Permafrost and Periglacial Proceses, 6: 147-171.

Hétu, B. and Vandelac, P., 1989. La dynamique des éboulis schisteux au cours de l'hiver, Gaspésie septentrionale, Québec. Géographie physique et Quaternaire, 43:389-406.

Hétu, B., Van Steijn, H. and Vandelac, P., 1994. Les coulées de pierres glacées: un nouveau type de coulées de pierraille sur les talus d'éboulis. Géographie physique et Quaternaire, 48: 3-22.

Hétu, B., Van Steijn, H. and Bertran, P., 1995. Le rôle des coulées de pierres sèches dans la genèse d'un certain type d'éboulis stratifiés. Permafrost and Periglacial Processes, 6: 173-194.

Hooke, R.L., 1967. Processes on arid-region alluvial fans. Journal of Geology, 75:438-460.

Jorda, M., 1988. Modalités paléoclimatiques et chronologiques de la déglaciation würmienne dans les Alpes françaises du sud. Bulletin de l'Association française pour l'étude du Quaternaire, 1988, 2-3:111-122.

Larsson, S., 1982. Geomorphological effects on the slopes of Longyear Valley, Spitsbergen, after a heavy rainstorm in July 1972. Geografiska Annaler, 64A: 105-125.

Lowe, D.R., 1979. Sediment gravity flows: their classification and some problems of application to natural flows and deposits. SEPM Special Publication, 27: 75-82.
McEachren, D.B., 1986. Stereo, the stereographic projection programme. Apple Macintosh computer, version 1.3.

Nemec, W. and Postma, G., 1993. Quaternary alluvial fans in southwestern Crete: sedimentation processes and geomorphic evolution, p. 235-276. In M. Marzo and C. Puigdefábregas, eds., Alluvial Sedimentation. International Association of Sedimentologists. Special Publication 17, Blackwell, Oxford.

Pérez, F.L., 1990. Surficial talus fabric and particle gliding over snow on Lassen Peak, California. Physical Geography, 11:142-153.

Rapp, A. and Nyberg, R., 1988. Mass movements, nivation processes and climatic fluctuations in northern Scandinavian mountains. Norsk Geografisk Tidsskrift, 42 : 245-253.

Takahashi, T., 1978. Mechanical characteristics of debris flow. Journal of the Hydraulics Division, ASCE, 104: 1153-1169.

1980. Debris flow on prismatic open channel. Journal of the Hydraulics Division, ASCE, 106: 381-396.

Texier, J.-P. and Bertran, P., 1993. Données nouvelles sur la présence d'un pergélisol en Aquitaine au cours des dernières glaciations. Permafrost and Periglacial Processes, 4: 183-198.

Tricart,J. and Cailleux, A., 1967. Le modelé des régions périglaciaires. SEDES, Paris, $512 \mathrm{p}$.

Van Steijn, H., 1988. Debris flows involved in the development of Pleistocene stratified slope deposits. Zeitschrift für Geomorphologie, Neue Folge, Supplement-Band, 71 : 45-58.

Van Steijn, H., 1991. Frequency of hillslope debris flows in a part of the French Alps. Turkish Bulletin of Geomorphology, Ankara, 19: 83-90.

Van Steijn, H., Bertran, P., Francou, B., Hétu, B. and Texier, J.-P., 1995. Models for the genetic and environmental interpretation of stratified slope deposits - a review. Permafrost and Periglacial Processes, 6: 125-146.

Wasson, R.J., 1979. Stratified debris slope deposits in the Hindu Kush, Pakistan. Zeitschrift für Geomorphologie, Neue Folge, 23: 233-242.

Washburn, A.L., 1979. Geocryology. Edward Arnold, London, 406 p.

Woodcock, N.H., 1977. Specification of fabric shapes using an eigenvalue method. Geological Society of America, Bulletin, 88: $1231-1236$. 